\title{
Niesmak po lekturze Historii Kościoła
}

\author{
Aleksandra Polewska Akta Edessy. Historia Kościoła do \\ degustacji!, Rafael, Kraków 2015, 232 s.
}

W 2015 roku ukazała się praca Aleksandry Polewskiej pod intrygującym tytułem Akta Edessy. Historia Kościoła do degustacji! Tytuł, informacja z rewersu okładki oraz ilustracje (ser, winogrona, chleby, ryby) czy powielany przez wszystkie internetowe księgarnie opis reklamujący pozycję pozwalały sądzić, że ukazało się właśnie pionierskie dzieło z zakresu kościelnej antropologii codzienności, wkraczające na tereny dotąd szerzej nieomawiane i oferujące nowatorską perspektywę oglądu historii Kościoła. Jedzenie w ostatnich latach coraz częściej staje się przedmiotem zainteresowania różnych dziedzin humanistyki, ukazują się liczne publikacje traktujące o wzajemnym wpływie historii i kuchni, o wpisanym w kulinaria dyskursie tożsamościowym, o roli jedzenia w kreowaniu narodowego autowizerunku, w obrzędach, rytuałach itp. ${ }^{2}$ Publikacjom towarzyszą konferencje naukowe, na których do wspólnego stołu (obrad) zasiadają socjologowie, antropolodzy, historycy sztuki, językoznawcy, literaturoznawcy,

${ }^{1}$ „Lekka w formie, osobliwa, pisana z niemałym dystansem i, co najbardziej zaskakujące, utrzymana w kulinarnej narracji. Najbardziej oryginalna książka, dzięki której poznamy w pigułce historię naszego Kościoła”.

${ }^{2}$ Kilka klasycznych pozycji: Barthes R., 2001, Czytanie Brillat-Savarina, w: idem, Lektury, Warszawa, s. 179-202; Brillat-Savarin A., 1977, Fizjologia smaku albo Medytacje o gastronomii doskonatej, przeł. J. Guze, oprac. W. Zawadzki, Warszawa; Certeau de M., Giard L., Mayol P., 2011, Wynaleźć codzienność. 2. Mieszkać, gotować, przeł. K. Thiel-Jańczuk, Kraków; Higman, B.W., 2012, Historia żywności. Jak żywność zmieniała świat, przeł. A. Kunicka, Warszawa; Lévi-Strauss C., 2010, Surowe i gotowane, przeł. M. Falski, S. Cichowicz, Warszawa; Łeńska-Bąk K., 2010, O pokarmach, smakach i utraconych znaczeniach, Opole; Mennell S., Murcott A., van Otterloo A.H., 1993, The sociology of food: eating, diet and culture, London; Wieczorkiewicz A., 2008, Apetyt turysty. O doświadczaniu świata w podróży, Kraków. 
religioznawcy ${ }^{3}$. Problemem kulinariów w literaturze i narracjach tożsamościowych zajmuję się od pewnego czasu, więc uradowała mnie myśl, że oto właśnie mam szansę na poznanie historii Kościoła „od kuchni”.

Ofiarowanie przez Chrystusa własnego ciała i krwi na pokarm, baranek ofiarny czy ryba jako symbol chrześcijan to najbardziej wyraziste i powszechnie znane symbole niemal narzucające konieczność podjęcia „kuchennych dziejów” Kościoła. Kolejnym, wyjątkowo ważnym tropem interpretacyjnym jest wieczernik, który zresztą Polewska traktuje jako miejsce narodzin Kościoła. W wieczerniku ustanowiony został Najświętszy Sakrament, nastąpiło znaczące umywanie nóg, był on miejscem schronienia apostołów, zesłania Ducha Świętego, wspólnego spożywania, a zatem eksponowania integracyjnej roli stołu (ołtarza), biesiadowania, roli pokarmu w obrzędach, w tym w rytuałach przejścia i fazie liminalnej (Chrystus przed ukrzyżowaniem zasiada $\mathrm{z}$ apostołami wokół stołu wieczernika i po zmartwychwstaniu przybywa do nich, zgromadzonych także w wieczerniku). Kliknęłam zatem, kupiłam, kurier dostarczył, rozpakowałam, zajrzałam do zamieszczonego na końcu spisu treści i doświadczyłam pierwszych wątpliwości, bo spośród dwunastu rozdziałów tylko jeden pozwalał mieć nadzieję na narrację związaną z pożywieniem: Penicillum camemberti. Wróciłam do początku (wstępu):

\begin{abstract}
„Życie jest jak uczta. Jestem już przy serach, a zapewniam was, że one także są wyborne" - mawiał papież Jan XXIII, zbliżając się do końca swej ziemskiej wędrówki. Ja zaś, zainspirowana słowami wielkiego Świętego, pozwolę sobie stwierdzić, że ucztą jest również historia Kościoła. Wyobraźmy więc sobie wielki stół. (...) Przy stole stoi osoba, która zaprasza nas do degustacji i wyjaśnia, że mamy przed sobą przysmaki pochodzące ze wszystkich stron świata. Dodaje, że przyrządzone zostały zarówno według receptur powstałych w późnym antyku, średniowieczu, renesansie, w dobie wojen napoleońskich, jak i w roku 2000 (s. 5).
\end{abstract}

Czekam zatem na taką ucztę składającą się z kulinarnej narracji o Kościele, a tym razem, przyznaję, dałam się zwieść metaforze i otrzymałam z całą pewnością nieklasyczną pozycję historyczną. Praca Aleksandry Polewskiej,

${ }^{3}$ Dla przykładu: Kuchnia i stół w komunikacji społecznej, Wrocław, 15-17 października 2015; Food Culture in Central Europe (Austria, Belarus, Bosnia and Herzegovina, Bulgaria, Croatia, Czech, Estonia, Germany, Hungary, Latvia, Lithuania, Moldova, Montenegro, Poland, Romania, Russia, Serbia, Slovakia, Slovenia, Ukraine), Warszawa, 19-20 maja 2016 roku. 
choć zawiera bibliografię (w której brak opracowań fundamentalnych ${ }^{4}$ ) i chętnie streszcza lub cytuje różnorodne źródła, to ani cytatów, ani wyraźnie zapożyczonych myśli, tez czy wniosków nie opatruje przypisami, co stanowi przecież ogromne nadużycie w zakresie własności intelektualnej. Zdarza się, że powołuje się na prace autora, który nie figuruje w bibliografii (np. na s. 144 przytacza opinię nieobecnej w spisie literatury Silvany Seidel Menchi). Choć opracowanie Polewskiej ma ambicje wpisać się w nurt historii Kościoła, to na równi ze źródłami historycznymi i naukowymi traktuje tradycję, podania, objawienia (chętnie sięga po teksty niemieckiej mistyczki Anny Katarzyny Emmerich), cuda czy Ewangelię. Wybiera te źródła, które - jak przyznaje - imponują jej sposobem prowadzenia narracji, gdyż autorzy „umieli rozkochiwać czytelnika w swych opowieściach. Ich wiedza historyczna splatała się nierozerwalnie z talentem literackim”, a język ,,przenikał duch pasji” (s. 25). Najwyraźniej sama również pragnie rozkochać czytelnika w swojej opowieści. Wśród pozycji, którymi jest zafascynowana czy zauroczona, znajdują się właśnie objawienia Anny K. Emmerich, Historia kościelna Euzebiusza z Cezarei, dzienniki Krzysztofa Kolumba, Kwiatki św. Franciszka czy listy św. Franciszka Ksawerego. Do dziejów Kościoła włącza także narracje apokryficzne (np. zaliczenie Jezusa do panteonu bóstw rzymskich przez cesarza Tyberiusza, samobójstwo Piłata).

W swojej historii Kościoła Aleksandra Polewska skupia uwagę na faktach, ale też niepotwierdzonych przypuszczeniach - co skutkuje częstymi sformułowaniami typu: „nie wiemy”, „miał wystawić”, „miał zginąć”, „miał uwolnić”, „,wiadomo niewiele” (s. 36) - czy przeżyciach i wewnętrznych przemianach bohaterów (np. w rozdziale I Nowa cywilizacja mówi o ,przemienieniu”, które było udziałem apostołów, a w rozdziale XI Opowieści słonecznego blasku o przemianie duchowej - ale nie nawróceniu, bo „masońskie przekonania blokowały jego serce na łaskę wiary”, s. 213 - portugalskiego dziennikarza Avelino de Almeidy, obserwującego cud słoneczny w Fatimie 13 października 1917 roku). Interesują ją zatem nie tylko dzieje Kościoła (jako instytucji, organizacji), ale także jego

\footnotetext{
${ }^{4}$ Kumor B., 2001, Historia Kościoła katolickiego, t. 1-3, Lublin; Rogier L.J., Aubert R., Knowles M.D., et al. (red.), 1984-1988, Historia Kościoła, t. 1-5, przeł. M. Tarnowska (tom 1), R. Turzyński (tom 2), J. Piesiewicz (tom 3), T. Szafrański (tom 4 i 5), Warszawa; Encyklopedia katolicka, 1973-2014, Lublin; Runciman S., 1997, Dzieje wypraw krzyżowych, t. 1-3, wyd., 3, przeł. J. Schwakopf, Warszawa.
} 
duchowość. Widzi również potrzebę pouczenia, czym jest i powinien być Kościół w sensie duchowym. Trudno jednak rozważania te uznać za refleksję z zakresu katolickiej/chrześcijańskiej duchowości, dogmatyki czy teologii. Polewska oferuje oczywistości w postaci haseł o cywilizacji miłości i ojczyźnie w niebie. Otrzymujemy więc zbudowaną z wybranych zdarzeń - w ocenie autorki najbardziej zajmujących, gdyż jej celem było zainteresowanie czytelnika - historię opartą na ciekawostkach i przesiąkniętą wiarą. Wynikające $\mathrm{z}$ wiary przekonania towarzyszą prezentacji dziejów Kościoła. W takiej optyce niektóre fakty historyczne prezentowane są wyłącznie w kategoriach cudu: cud pod Lepanto (1571), zwycięstwo chocimskie (1621) czy wiktoria wiedeńska (1683).

Rozdział pierwszy Nowa cywilizacja dotyczy wydarzeń i miejsc wiązanych z narodzinami Kościoła (wieczernik, Pięćdziesiątnica). W rozdziale drugim Acta Edessy, zgodnie z narracją Euzebiusza, za pierwszego chrześcijańskiego władcę autorka uznaje Abgara V, a Edessę (w której mieszkał) za pierwsze państwo chrześcijańskie. Jednym z dowodów potwierdzających, że Edessa była siedzibą pierwszego chrześcijańskiego władcy ma być mandylion - utożsamiony z całunem turyńskim. Nieco dziwi, że w tym kontekście Polewska nie mówi także o chuście Weroniki czy o chuście z Manopello. Kolejne trzy wieki z dziejów Kościoła (do czasów Dioklecjana) zilustrowane zostały doświadczeniami i życiorysami męczenników oraz prezentacją różnorodnych form prześladowań (rozdział III Niebiescy niezłomni). Podstawowym źródłem informacji jest tu dzieło Euzebiusza $O$ męczennikach palestyńskich, które Polewska streszcza lub cytuje, zwracając szczególną uwagę na dosłowność i obrazowość opisów tortur starożytnego narratora. Jak w innych fragmentach pracy, tak i tutaj autorka nie poprzestaje na podaniu faktów, ale interpretuje je w kontekście wiary i roli dla dalszych losów Kościoła.

Niezwykle zwięzły (zaledwie półtorej strony) rozdział czwarty Trzy zdania, które odmienity świat traktuje o edykcie mediolańskim z 313 roku, który przemodelował wzajemne stosunki Kościoła i państwa, odwrócił los chrześcijan, odtąd zasiadających na tronie dotychczasowego wroga - Imperium Romanum. Jeden z nich, Teodozjusz I, uczynił chrześcijaństwo religią państwową. Negatywną konsekwencją tego faktu jest - zauważa Polewska - możliwość ingerencji państwa w działalność Kościoła i jego podporządkowania (o zagrożeniach wynikających ze zbyt daleko idących 
prób ingerencji Kościoła w funkcjonowanie państwa nie wspomina). Spośród licznych przykładów walki o „rząd dusz” pomiędzy władzą świecką i kościelną wyjątkowo drastycznie rysuje się okres Wielkiej Rewolucji Francuskiej w regionie Wandei. Wydarzeniom tym poświęcono rozdział dziesiąty Penicillum camemberti. Klamrą spinającą rozdział jest opowieść o benedyktyńskim mnichu serowarze (Charle-Jaean Bouvoust z Brie), który zachowując wierność Kościołowi rzymskiemu i uciekając przed prześladowaniami jakobinów zmuszających duchowieństwo do złożenia przysięgi na Konstytucję Cywilną Kleru, znalazł schronienie u wdowy w miejscowości Camembert. Z wdzięczności za gościnność i odwagę podobno (narracja znów oparta jest na podaniu) przekazał jej przepis na przygotowanie sera zwanego dzisiaj camembert. Narracja odnosząca się do kulinariów stanowi znikomą część rozdziału, sprowadzającego się do relacjonowania terroru stosowanego wobec duchownych i świeckich zwolenników wierności Rzymowi: masowe mordy, palenie kościołów, konfiskata majątku, niszczenie relikwii. Przeciw decyzjom władz wystąpiła ludność Wandei. Po początkowych sukcesach powstania Wandejczycy ponieśli jednak całkowitą klęskę i zostali wymordowani. Wydarzenia te Polewska nazywa pierwszym ideologicznym ludobójstwem, które miało stanowić inspirację dla Lenina i następnie Stalina (s. 192-194). Dość dziwna to i zaskakująca teza: Republika Francuska zostaje przedstawiona jako zarzewie wszelkiego późniejszego zła bolszewickiego, a dorobek Rewolucji Francuskiej sprowadzony do pasma mordów i działań antykościelnych. Autorka przypomina też pogląd, że źródłem dzisiejszej laicyzacji Francji są wydarzenia związane z rewolucją, a zeświecczenie nie ma nic wspólnego z dobrowolnym odejściem obywateli od chrześcijaństwa. Czy rzeczywiście wieki przynależności do Kościoła katolickiego można zniweczyć przez dziesięciolecie w sposób tak fundamentalny, że niemożliwe byłoby odrodzenie wiary przez kolejne stulecia? Rewolucja to raczej efekt niż przyczyna laicyzacji.

Cechą charakterystyczną opracowania Aleksandry Polewskiej jest dążenie do wybielenia wszelkich ciemnych plam w historii Kościoła. Jeżeli pewne okresy, wydarzenia, postawy nie dają się zanegować, wybielić, pokazać w nowym, lepszym, czytaj: ,prawdziwym” świetle, to jako ich sprawca wskazany zostaje Szatan (v. dotyczący schizmy rozdział VII Ten, który dzieli $\mathrm{i}$ in.). Na liście wydarzeń wymagających „właściwej” interpretacji znajdują się więc wyprawy krzyżowe, inkwizycja, palenie czarownic. 
Dla przykładu kilka tytułów lub podtytułów rozdziałów: Krucjaty - czarna karta Kościoła? (s. 81), Jak inkwizycja ratowała czarownice (rozdział VIII, s. 139), Na ratunek czarownicom (s. 146). Autorka twierdzi, że zasadność weryfikacji „czarnych legend” kryje się w faktach historycznych, są to trzy rzeczywiste przyczyny, dla których Urban II wszczął „wojnę sprawiedliwą" (podaje je na s. 82). Tymczasem to nie zasadność wypraw jest źródłem ich negatywnego obrazu, lecz zdarzające się w ich trakcie „ekscesy” - jak eufemistycznie pisze Polewska, uznając je za „temat na odrębną opowieść" (s. 83). Twierdzenia historyków o kierowaniu się przez krzyżowców chęcią zdobycia bogactwa, władzy, tytułów czy haremów „,neutralizuje” uwagą, że uczestnikom nie obiecywano korzyści materialnych. Przejawy negatywnych zachowań krzyżowców uznaje za incydentalne i niezgodne z wolą Urbana. Brak złych intencji papieża to - odnosi się wrażenie - dostateczny (i ostateczny) powód do odrzucenia zasadności pamiętania o krwawym obliczu wypraw. W procesie wybielania autorka sięga po zabieg ,,analizy tekstu”, wskazuje na metaforyczność (czytaj: nieprawdziwość) przekazów:

Okrutne, a zarazem zastanawiająco ogólnikowe opisy z ówczesnych kronik wykorzystywane są nader chętnie przez krytyków wypraw krzyżowych jako dowód na to, że były one samym złem. Tymczasem drastyczna forma relacji była najprawdopodobniej w pełni świadomie zastosowana przez dziejopisarzy trikiem [pisownia oryginalna - K.P.-M.], aby podkreślić apokaliptyczny charakter wydarzenia. Zwróćmy chociażby uwagę na fakt, że we krwi brodzić się nie da z tego prostego powodu, że krew krzepnie (s. 84).

Z przykrością należy odnotować, że powyższy fragment zdradza niekompetencję w zakresie umiejętności korzystania ze źródeł oraz ignorowanie w pełni wiarygodnych badań prowadzonych przez historyków na całym świecie. Ostatnie zdanie z cytatu może jedynie służyć ku uciesze, bo trudno je komentować. Autorka ma nadmierną skłonność do dosłownego odczytywania treści zawartych w różnorodnych źródłach, jakby bez świadomości obowiązujących w danej epoce konwencji. Stosowane w listach przez Krzysztofa Kolumba zwyczajowe zwroty inicjujące, charakterystyczne dla ówczesnej sztuki epistolarnej, w których nadawca odwołuje się do Boga i Trójcy Przenajświętszej, odczytuje więc jako wyraz głębokiej wiary i osobistej relacji z Bogiem, odrzucając przy tym badania historyczne: 
Dzienniki amerykańskich wypraw Kolumba, a także jego mnogie listy adresowane do władców Hiszpanii, papieża czy syna Diego zaskoczyły mnie licznymi i bardzo jednoznacznymi odniesieniami do Boga. (...) Część historyków stoi na stanowisku, że odwołania do Stwórcy w Kolumbowych listach są jedynie strategiczną zagrywką, stosowaną, by przypodobać się tak realnym, jak i potencjalnym patronom i sponsorom wypraw (...) - teoria ta mogłaby być generalnie zasadna, gdyby nie fakt, że Kolumb pisze o Bogu jak o kimś, z kim ma niemal osobistą relację. (...)

„W imię Trójcy Przenajświętszej, która natchnęła mnie i doprowadziła do pełnego zrozumienia, że mógłbym żeglując dotrzeć do Indii wypłynąwszy z Hiszpanii i przepływając Morze Oceanne w kierunku Zachodu”.

Widzimy zatem, że nasz odkrywca nie przypisuje sobie zasług związanych z odnalezieniem nowych ziem, ale podkreśla, że odkrył je z natchnienia Bożego (s. 154-155).

Komentarz autorki do cytowanego fragmentu listu zdradza brak profesjonalizmu i wiedzy z zakresu poetyki tekstu. Kto ma być odbiorcą wizji dziejów odrzucającej dotychczasowy dorobek badań historycznych i przyznającej sobie prawo do jedynej właściwej interpretacji faktów i źródeł? Podstawowym celem wypraw Kolumba - w perspektywie autorki - była chrystianizacja odkrytych terenów, a dowodem jego troski o nawrócenie pogan jest cytowany (s. 156-157) list do papieża Aleksandra VI. Wielki żeglarz prosi w nim o misjonarzy, którzy towarzyszyliby mu w kolejnej wyprawie. Przy okazji Polewska dementuje opinię, jakoby Kościół miał udział w siłowej chrystianizacji: przypisuje ją wyłącznie konkwistadorom, władcom, książętom, przybyszom dbającym o interesy prywatne. Zwraca także uwagę na ogromną determinację i odwagę misjonarzy, którzy ,ginęli nierzadko pośród wielkich mąk, gdyż niektóre szczepy bywały bardzo okrutne dla misjonarzy" (s. 158). Czy z perspektywy XXI wieku i z perspektywy Polski przeczulonej na punkcie ochrony własnej kultury można dzisiaj pisać o ekspansywnej chrystianizacji Ameryki, przerzucając się jedynie odpowiedzialnością za niewątpliwe „nadużycia” rozwiązań siłowych? Czy nie należałoby podjąć trudnego wątku, jakim jest prawo każdej społeczności do zachowania własnej kultury, wierzeń, obrzędów oraz rozważyć pozytywne i negatywne skutki kolonizacji, rozpoczętej wraz z zamorskimi odkryciami Kolumba?

W rozdziale ósmym Polewska postanowiła rozprawić się z niewłaściwym wizerunkiem inkwizycji, m.in. z czarną legendą Bernarda Gui, który spośród 633 wyroków skazujących (a ogółem ponad 900) wydał - w jej opinii - ,zaledwie” 41 wyroków śmierci, 308 kar więzienia czy nakazał 
69 ekshumacji połączonych z paleniem. Autorka skupia się na eksponowaniu zalet Świętego Oficjum i demaskowaniu propagandy o grozie inkwizycji, szerzonej - jej zdaniem - przede wszystkim przez protestantów. Wśród walorów systemu wymienia: stosowanie procedur zbliżonych do współczesnych, skrupulatność, sumienność i bezstronność, akcentowanie konieczności poprawy, a nie chęci karania. Fakt, że niewiele procesów przebiegało zgodnie z procedurami, a udostępnione przez Jana Pawła II archiwa watykańskie dokumentują wielorakie błędy, nie zwraca szczególnej uwagi autorki. W kwestii czarownic skupia się ona na opisie przykładów ich ratowania i wydanych przez Oficjum zaleceniach wielostopniowej weryfikacji oskarżeń. Jedynie na marginesie dodaje, że stosy ze skazanymi kobietami płonęły, bo rzymskie podręczniki ignorowano. Opowieść o tym Jak inkwizycja ratowała czarownice rozpoczyna (często powtarzana przez wątpliwych obrońców Kościoła) teza, że badania archiwów prowadzą do wniosku o znacznie mniejszej liczbie spalonych na stosach heretyków niż się powszechnie uważa. Konstatację tę przypomina także Adam Szostkiewicz, jednak w swym tekście (publicystycznym, nie pretendującym do naukowości, jak praca Polewskiej) pisze również o okrutnym losie tych, którzy przez Świętą Inkwizycję zostali uznani winnymi i zwraca uwagę, że czarnej legendy inkwizycji nie wyssali z palca wrogowie Kościoła ${ }^{5}$. Upominam się o taką wieloaspektową perspektywę oglądu i prezentacji faktów, w przeciwnym wypadku należy uznać, że dokonywana jest świadoma manipulacja danymi i rezultatami badań. Warto odnotować, że rozdział ten - delikatnie mówiąc - wiele przejmuje z książki Michaela Hesemana Ciemne postacie w historii Kościoła (Kraków 2013). Oczywiście tekst konsekwentnie nie jest opatrywany przypisami. Kiedy po lekturze Polewskiej sięga się po Hesemana, to narracja okazuje się niezwykle znajoma.

${ }^{5}$ Trafne konkluzje Szostkiewicza: „Posoborowy Kościół rzymski wielokrotnie wyrażał skruchę z powodu ekscesów inkwizycji. Przepraszał za nie Jan Paweł II. Nie spodobało się to odłamowi katolików, którzy uważają, że przeciwnicy Kościoła świadomie stworzyli czarną legendę inkwizycji, by kompromitować katolicyzm jako religię ciemnoty i represji. Co innego jednak rzetelne badania historyczne i wynikające $\mathrm{z}$ nich korekty, a co innego ocena moralna. Współczesnej wrażliwości nie wypada przerzucać się liczbami: że spalono tylko tylu, a aż tylu darowano życie i ukarano łagodnie. Zło nie polega na liczbach, tylko na mechanizmie służącym temu, by przemocą bronić jedynie słusznej wiary”. Szostkiewicz A., 2009, Inkwizycja mniej straszna. Ogniem, słowem i żelazem, „Polityka” 23.11., <http://www.polityka.pl/ tygodnikpolityka/historia/1501047,1,inkwizycja-mniej-straszna.read>, 4.03.2016. 
Do wątków kulinarnych powraca autorka w rozdziale szóstym, dotyczącym monastycyzmu: Monastycyzm jakiego nie znacie. Tutaj także wychodzi z założenia, że potrzebne jest obalenie błędnych przekonań na temat Kościoła. Jednym z nich jest ponoć powszechne przekonanie, że Kościół zawsze był przeciwny wszelkiemu rozwojowi (s. 96). Przypomina więc, zakładając że jej czytelnik nigdy nie spotkał się z tymi informacjami, o działających w klasztorach lekarzach, artystach, uczonych, dyplomatach, poliglotach, politykach czy finansistach. Niewielka część tego rozdziału nawiązuje do wątku kulinarnego: Dzieje cappuccino, czyli monastycyzm od kuchni. Pomysł na cappuccino autorka przypisuje włoskiemu kapucynowi. Ze względu na nadmiar pożywienia produkowanego w przyklasztornych ogrodach oraz dostarczanego przez okolicznych mieszkańców, mnisi zmuszeni byli do „eksperymentowania": suszenia, marynowania, kiszenia, smażenia konfitur, produkcji soków. W rozwoju sztuki kulinarnej z zakonami mogły wówczas konkurować jedynie dwory królewskie. Interesujące byłoby rozwinięcie wątku dotyczącego postów, które wprawdzie często stosowano, jednak zalecenia były dość odległe od współczesnych wyobrażeń. Inaczej niż dzisiaj definiowano potrawy mięsne, z których wykluczano wszystko, co lata i pływa (także bobry). Bracia stawali się mistrzami w produkcji serów, specyfików leczniczych na bazie ziół, win, piw, miodów pitnych czy szampana. Polewska przypomina o roli zakonnika z opactwa w Szampanii Dom Pierre'a Pérignona w wynalezieniu szampana, choć nie o samo wynalezienie chodzi, a o technikę mieszania.

Szkoda, że podobna narracja nie została rozwinięta w całej książce, że nie są to Dzieje Kościoła od kuchni. Byłyby lekturą naprawdę intrygującą, a nie irytującą. Kościół nie potrzebuje wybielania za wszelką cenę: zarówno Leon XIII, otwierając w 1881 roku dla historyków Tajne Archiwum Watykańskie, jak i Jan Paweł II, odtajniając w 1998 roku watykańskie archiwa inkwizycji, a w 2002 roku udostępniając dokumenty dotyczące Niemiec za okres 1922-1939, twierdzili, że historia nie może zatajać prawdy, podkreślając przy tym wyzwalającą moc szczerości. Mówiąc o sile prawdy, polski papież prosił o wybaczenie, nie o wybielenie. Dlatego też, upominając się o rzetelność badawczą i odpowiedzialność za słowo kierowane do odbiorcy, poświęciłam uwagę tej pseudonaukowej publikacji traktującej także o relacjach państwa i Kościoła. 